\title{
Would a single regional visa encourage tourist arrivals in southern Africa?
}

\author{
Anneli Douglas, Berendien A Lubbe \& Elizabeth A Kruger ${ }^{1}$
}

Although many studies have been done of factors impeding Africa's development as a tourism destination, few have focused on southern Africa, and to date none have questioned whether the current visa requirements affect the region's tourism industry. This paper investigates the potential impact of the so-called Univisa, a single visa for the SADC region proposed by SADC and the Regional Tourism Organisation of Southern Africa (RETOSA). It examines the possible effect of visa requirements on a destination's accessibility and visitor numbers. Two surveys revealed that inbound and outbound tour operators were relatively positive about the benefits the proposed Univisa would bring, but were concerned about other factors hindering tourism development in the region. The study revealed the complexities of a regional visa and found that even though a regional visa might alleviate some problems, it cannot be seen as an answer to the slow development of tourism in this region.

Keywords: tour operator; visa; Univisa; tourism development; SADC (Southern African Development Community)

\section{Introduction}

Tourism has long been seen as 'the salvation for Africa's economic woes, poverty and underdevelopment' (Ferreira, 2004:303), but although the continent's tourism potential is significant it remains underdeveloped. The good news is, however, that even though tourism activity is still focused on the developed countries of the Americas and Europe, new touristgenerating and tourist-receiving markets are proliferating in the developing regions of East Asia and the Pacific, South Asia, the Middle East and Africa (Dabour, 2001). To earn foreign exchange and create jobs, many developing countries are building up their tourism sectors and tourism-related industries (Naude \& Saayman, 2005) and strengthening their regional collaboration.

A number of studies have been conducted to identify the determinants of tourism development in Africa and the factors inhibiting the development of Africa as a tourism destination. Naude and Saayman (2005) found that political stability, personal safety, health risks and available infrastructure are some factors that determine whether a tourist will visit the continent. Brown (2000) studied the effect of political risks and other barriers to tourism promotion in Africa and Gauci et al. (2002) investigated challenges and opportunities for tourism in Africa. Studies have also focused specifically on tourism development in the SADC region (Page, 1999; Cleverdon, 2002; Ferreira, 2004) and in specific countries in this region, such as Lesotho and South Africa (EIF, 2003; Ferreira, 2004; Rogerson \& Visser, 2004, 2006). Most of these studies highlight access to a destination as a vital factor for

\footnotetext{
${ }^{1}$ Respectively, Senior Lecturer; Professor; and Part-time Lecturer, Department of Tourism Management, University of Pretoria. Corresponding author: anneli.douglas@up.ac.za
} 
tourism development but none has investigated the influence that visa requirements may have on accessibility.

This study therefore aimed to determine the possible influence that a single regional visa (the proposed Univisa) will have on the accessibility of the SADC region, and whether this visa is likely to encourage or deter tourism in the region. More specifically, it aimed to determine both inbound and outbound tour operators' perceptions of the potential impact of the Univisa on tourist arrivals and subsequently on their businesses. Outbound tour operators create packages and tours for tourists travelling to destinations outside their home country, while inbound tour operators handle arrangements inside the destination country for these incoming tourists. The perceptions of both types of operator are important since they are dealing with the same target market, for example tourists from the US visiting South Africa.

The remainder of the paper is structured as follows. We first explain the background to the study, providing a brief context of tourism in Africa and highlighting the factors that are inhibiting the continent's and more specifically the SADC region's development as a tourism destination. We explain the rationale for the establishment of the SADC region and the role that SADC plays in tourism development. We then set out the advantages and disadvantages for a country of either having or not having visa requirements. Following this we discuss the proposed Univisa, and also the Schengen visa, since the Univisa is based on the principles of the Schengen and is similar to it. We describe our methodology and discuss and summarise the findings of the study, after which we conclude with a discussion of theoretical and managerial implications of the Univisa and suggest directions for further research.

\section{Background to the study}

\subsection{Tourism development in Africa}

A number of factors still inhibit Africa's, and particularly the SADC region's, development as a tourism destination of choice (see Table 1). However, notwithstanding these obstacles there is optimism about tourism development in the SADC region. Cleverdon (2002) is of the opinion that the region's natural and sociocultural resources are in line with the growing interests of the international tourism market, but that growth will remain below potential unless efforts are made to improve international access and address the major (real and imagined) threats to tourist safety. According to Dwyer (in Heath, 2002) the accessibility of a destination, is determined by a number of factors: the frequency, ease and quality of air, sea and land access; aviation regulations; entry permits; visa requirements; route concessions; airport capacities; and competition among carriers. This paper focuses specifically on the influence of visa requirements on the accessibility of the SADC region and how it aims to improve accessibility by introducing a single regional visa (the so-called Univisa). 
Table 1: Barriers to tourism development in Africa and the SADC region

\begin{tabular}{|c|c|c|}
\hline Authors & Context of the study & $\begin{array}{c}\text { Factors inhibiting tourism } \\
\text { development }\end{array}$ \\
\hline \multirow{2}{*}{$\begin{array}{l}\text { Naude \& Saayman } \\
\quad(2005)\end{array}$} & Determinants of tourist arrivals in Africa & Political instability \\
\hline & & $\begin{array}{l}\text { Threat to personal safety } \\
\text { Health risks } \\
\text { Poor infrastructure } \\
\text { Inadequate tourism marketing } \\
\text { efforts } \\
\text { Geography - disease burden } \\
\text { Geography - country unable to } \\
\text { provide beach holidays }\end{array}$ \\
\hline \multirow[t]{2}{*}{ Brown (2000) } & $\begin{array}{l}\text { Political risk and other barriers to tourism } \\
\text { promotion in Africa: perceptions of US- } \\
\text { based travel intermediaries }\end{array}$ & Political instability \\
\hline & & $\begin{array}{l}\text { Poor service quality } \\
\text { Poor infrastructure } \\
\text { Health risks }\end{array}$ \\
\hline \multirow[t]{2}{*}{$\begin{array}{l}\text { Teye (in Brown, } \\
\text { 2000) }\end{array}$} & & Political risks \\
\hline & & $\begin{array}{l}\text { Shortage of investment capital } \\
\text { Remoteness of destination from } \\
\text { main tourist generating markets }\end{array}$ \\
\hline \multirow[t]{2}{*}{$\begin{array}{l}\text { Ankomah \& } \\
\text { Crompton (in } \\
\text { Brown, 2000) }\end{array}$} & & Negative images \\
\hline & & $\begin{array}{l}\text { A shortage of foreign exchange for } \\
\text { tourism development } \\
\text { Insufficient skilled manpower } \\
\text { Weak institutional frameworks for } \\
\text { tourism planning } \\
\text { Political instability }\end{array}$ \\
\hline \multirow[t]{2}{*}{ Gauci et al. (2002) } & $\begin{array}{l}\text { Challenges and opportunities for tourism in } \\
\text { Africa }\end{array}$ & Poor infrastructure \\
\hline & & $\begin{array}{l}\text { Inadequate accommodation } \\
\text { Insufficient public health services } \\
\text { Poor telecommunication facilities } \\
\text { Security problems } \\
\text { High pricing of tourism services }\end{array}$ \\
\hline Cleverdon (2002) & $\begin{array}{l}\text { Tourism development in the SADC region: } \\
\text { opportunities and challenges }\end{array}$ & $\begin{array}{l}\text { High level of fragmentation among } \\
\text { operators } \\
\text { Division of the sector } \\
\text { Political and economic volatility } \\
\text { Weak tourism policy, planning and } \\
\text { institutions }\end{array}$ \\
\hline
\end{tabular}




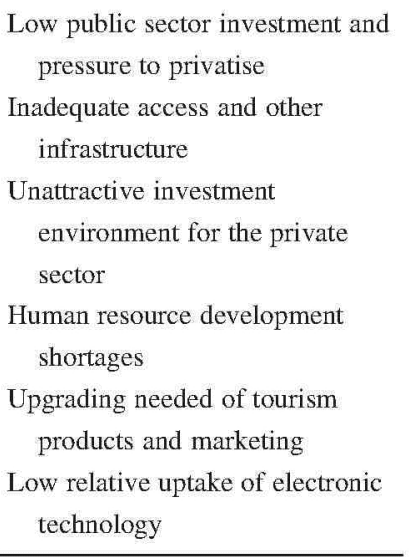

\subsection{Tourism development in the SADC region}

The Southern African Development Community (SADC) currently consists of the following 15 countries: Angola, Botswana, Democratic Republic of Congo, Lesotho, Madagascar, Malawi, Mauritius, Mozambique, Namibia, Seychelles, South Africa, Swaziland, United Republic of Tanzania, Zambia and Zimbabwe. SADC has set certain objectives for the development of the region, which are to:

- achieve development and economic growth, alleviate poverty, enhance the standard and quality of life of the peoples of southern Africa and support the socially disadvantaged through regional integration;

- evolve common political values, systems and institutions;

- promote and defend peace and security;

- promote self-sustaining development on the basis of collective self-reliance, and the interdependence of Member States;

- achieve complementarity between national and regional strategies and programmes;

- promote and maximise productive employment and utilisation of resources of the region;

- achieve sustainable utilisation of natural resources and effective protection of the environment; and

- strengthen and consolidate the long-standing historical, social and cultural affinities and links among the peoples of the region. (SADC, 2009)

Tourism is one way of achieving the objectives set by SADC. According to Heath (2002), if tourism can be developed in an appropriate manner, it could well become the engine of growth that can improve the quality of life for millions of Africans. According to the former South African Deputy Minister of Environmental Affairs and Tourism, Ms Rejoice Mabudafhasi, 'statistics of foreign arrivals gathered in the past few years provide clear evidence that the SADC region is amongst the top preferred destinations by tourists in the world' (Rannditsheni, 2008). According to RETOSA 'the region's tourist draw cards include wildlife, a rich variety of wilderness areas and natural wonders of the world, sandy beaches, mountain ranges and a rich historical and cultural heritage which straddle across national 
borders' (RETOSA, n.d.). To further encourage tourism growth and the benefits it brings, SADC has initiated discussion among its member states on the implementation of the socalled Univisa. The economic benefits accruing from this would include the distribution of income to many enterprises, some of which may belong to local communities; the optimisation of tourism income, which might lead to the creation of jobs; the abolition of poverty (Rannditsheni, 2008); and ultimately an increase in the GDP of the countries in the region (RETOSA, n.d.). At the time of writing, member states were still in the process of dealing with outstanding problems, for example costs, policy arrangements, measures and requirements for the issuing of the Univisa (Rannditsheni, 2008). According to Simba Mandinyenya, head of planning and development for RETOSA, four countries, Zimbabwe, Namibia, Mozambique and Swaziland, have already put the appropriate systems in place to implement the Univisa (Reinstein, 2011). Visa requirements and implementation processes can differ across countries and regions and the implementation of such systems may be relatively simple or quite complex.

\section{The purpose and problems of visas}

Whyte's explanation of the purpose and problems of visas is helpful:

It is a pre-emptive check on the bona fides of the traveller and his travel purpose and itinerary. Visa-free travel is simply the absence of a requirement to hold a visa, and is usually considered a privilege. Many visas require the traveller to submit his passport ahead of time to an embassy of the country he intends to visit. Other visas are purely formalities and are issued at land borders or ports of entry. These are often termed 'visa on arrival', and are little more than a simple form to complete, and an extra form of revenue generation for authorities, than a pre-emptive check on the visitor. To obtain a visa issued by consular officials ahead of time, the cost, time and effort involved for a traveller can be significant. (2009:295)

Whyte goes on to explain that a visa requirement may be bad for tourism because it 'discourages spur-of-the-moment, and even planned decisions to travel, whether for business or pleasure, particularly if the visa requirement involves much effort or cost to the potential traveller, such as the need to visit an embassy in person to make the visa application, and then return days or weeks later to collect it' (2009:303). Boratyński and Szymborska (2006:7) also say that a visa obligations can be a severe obstacle to travellers as they will have to "plan their trip well in advance, sometimes wait several weeks for a visa, often travel long distances to the nearest Consulate, wait in line, arrange an interview, cover their own costs and pay a visa fee ... all without a guarantee of getting a visa'. Tchorbadjiska (2007) adds that imposing visas causes administrative and financial burdens for prospective visitors and can result in a decline in the visitor numbers from countries that require visas.

A number of studies have highlighted the need for a country or region to simplify its visa requirements in order to improve its accessibility and develop its potential as a tourism destination. Enright and Newton (2005) are of the opinion that if a country does not provide visa-free privileges to nationals of its key tourist markets it is unlikely to remain competitive unless it has very special attractions. Tretheway and Mak (2006) observe that many developed countries have agreements which waive the need for a visa for short-stay tourists. This has significantly assisted tourism development in these countries. 
Rogerson and Visser (2006), using the city of Johannesburg as an example to illustrate international tourist flows and urban tourism in South Africa, identify visa access difficulties among other problems that are costing Johannesburg tourism millions of rand annually in lost income from regional tourists. Tosun et al. (2005), in a study of Greek-Turkish cross-border collaboration in tourism marketing growth, suggest among other tourism-boosting strategies the simplification of visa formalities and reduction or omission of visa fees and customs taxes for tourists who wish to visit both countries in one trip. Smeral (2009) observes that, with the recent world recession and economic crisis, many countries have become more aware of the economic importance of tourism and are taking measures to encourage tourism demand and assist tourism enterprises, including facilitating travel by simplifying the visa application process, cutting the costs of visas or abolishing visa requirements for certain source markets. Countries across Africa have various visa policies and some of them implement restrictive entry or visa policies, which can discourage travel to the region. Even though visas are usually valid for entrance into the country that issues them, SADC is considering the implementation of a Univisa, a single visa that would give right of entry to SADC member states. Common visas can encourage tourism and bring economic development to the region (WEF, WB \& ADB, 2011).

\section{The Univisa}

The concept of the Univisa is being promoted through the Regional Tourism Organisation of Southern Africa (RETOSA), a SADC body responsible for the development of tourism in 14 southern African countries: Angola, Botswana, Democratic Republic of the Congo, Lesotho, Madagascar, Malawi, Mauritius, Mozambique, Namibia, South Africa, Swaziland, Tanzania, Zambia and Zimbabwe (RETOSA, 2009). ${ }^{2}$ In essence, the Univisa will permit foreigners to enter all these 14 SADC member countries for tourism purposes. By assisting in the movement of international tourists, it will thus enlarge SADC's market share in world tourism and increase the region's income It will also increase regional tourism because it will remove or waive the visa requirements for regional travellers who desire to access the SADC region (RETOSA, n.d.). RETOSA believes that the Univisa will increase travel and tourism throughout the region since tourists will be able to move freely within member countries, with no additional requirement for individual visas per country (RETOSA, 2010). Apart from the obvious advantages of the Univisa, it should also benefit countries such as Lesotho that have very few consulates abroad. For Lesotho, the current visa system has major hindrances in that its diplomatic missions abroad are not permitted to issue multiple entry visas, and the cost of acquiring the first visa and then changing it to a multiple entry visa is the highest in the region. This means that tourists living in countries without diplomatic missions have an added burden when obtaining visas (EIF, 2003). Tourism Deputy Minister Todd Chilembo says that the Univisa proposal 'should make the SADC region more appealing to tourists, relative to other regions, as it expands the choice available to them' (cited by Zambian Economist, 2008). The Zambian Economist article (2008) notes, however, that the extent of the benefits of the proposed Univisa 'will depend on the extent to which air travel in the SADC can be further liberalised to allow tourists to move much more easily across countries'.

\footnotetext{
${ }^{2}$ Note that there is a difference between the members of RETOSA and the members of SADC listed in Section 2.2 above. Seychelles is not a member of RETOSA.
} 
At the time of writing, two common visas had been successfully implemented: the CA-4 Visa Unica Centroamericana for El Salvador, Guatemala, Honduras and Nicaragua, and the more well known Schengen Visa for 25 countries (WEF, WB \& ADB, 2011). The Univisa is intended to have the same advantage as these two: a visitor from outside a country who has a visa for that country can also use it to visit the other countries included in the agreement, while visitors from inside a country with visa-free privileges for that country have likewise visa-free privileges to the other countries in the agreement.

Rannditsheni (2008) envisages that the Univisa will operate on more or less the same basis as the European Schengen visa system, which is regarded as the best system by far.

\section{The European Schengen visa}

Twenty-two European Union countries (Austria, Belgium, the Czech Republic, Denmark, Estonia, Finland, France, Germany, Greece, Hungary, Italy, Latvia, Lithuania, Luxembourg, Malta, Netherlands, Poland, Portugal, Slovakia, Slovenia, Spain, Sweden), plus Norway, Iceland and Switzerland are currently fully applying the conditions of the Schengen legislation (European Commission, n.d.). Schengen standards allow for the removal of controls at the internal borders of the Schengen Member States, the development of common regulations on checks at the external borders and a common visa policy. This means that all Schengen countries produce visas under the same stipulations, taking into consideration each other's interests. A Schengen visa produced by one Schengen country is thus also applicable for the others, which is advantageous to nationals from a third country wanting to visit more than one Schengen country. The most noticeable effect of Schengen on travellers is that they do not have to present their passports when crossing borders between Schengen Member States. The main implication that Schengen has for an EU citizen is that such a citizen has the right to access any other EU country without having to obey specific formalities. All that is required from the citizen is a valid passport or identity document. A citizen of a non-EU country may access and travel within the Schengen area complying in full to the Schengen conditions for a period of up to three months (European Commission, n.d.).

A number of studies have investigated the effect that the Schengen agreement has had on the tourism industry of member states (Konečnik, 2002; Coles \& Hall, 2005; Puczko \& Ratz, 2006; Hughes \& Allen, 2009). Konečnik (2002) found that EU membership may in itself produce tourism arrivals by raising awareness of the quality of these countries through publicity. Puczko and Ratz (2006) studied product development and diversification of Hungary's tourism product after joining the EU in 2004 and established that Hungary benefited from a more positive image because they were seen to be 'more European' and tourists were more willing to visit countries that had finally made the break with their USSR controlled past. Coles and Hall (2005) observed that the eight Central and Eastern Europe countries that became part of the EU in 2004 noticed an increase in their standards of living, which resulted in increased domestic tourism and an outflow of tourists. Taking into account that the proposed Univisa will be based on the concept of the Schengen visa system, it would be reasonable to argue that the effect the Univisa will have on tourism development in the SADC region will be similar to the effect the Schengen has had on tourism development in Schengen member states. To illustrate this, we refer to Laitinen's study of Finland (2004). Finland's appeal and convenience as a tourist destination increased after it moved into the Schengen Treaty with the EU in 2001 , and it became possible for Finnish tourists to visit a number of European countries with the Finnish Embassy issuing the required Schengen visa. 
Thus, becoming part of the Schengen Treaty contributed to the development of Finland's incoming and outgoing tourism industry. Laitinen observes that 'this development had a significant impact on the fact that today Finland can be seen mainly as a gateway rather than a single destination for Chinese tourists' (2004:41).

To illustrate the possible advantages that a common visa can provide to the SADC region, we refer to a report commissioned by the World Economic Forum, the World Bank and the African Development Bank to study the effect that the implementation of the Schengen agreement has had on international tourist arrivals. The report showed that international tourist arrivals have increased substantially across all countries that have implemented the Schengen agreement. This is substantiated by a recent examination of Chinese tourists by The Economist, which discovered that once Switzerland implemented the Schengen agreement in 2008 the number of Chinese visitors immediately increased. While the socioeconomic conditions and attractions of Europe and Africa are of course not the same, a common visa scheme in the SADC region could lead to a significant increase in tourist numbers as has been the case for the Schengen member countries (WEF, WB \& ADB, 2011).

\section{Methodology}

Quantitative research techniques were used to determine what the effect of the Univisa would be on tourism arrivals to the SADC region. A survey was conducted during February and March of 2010. Tour operators were selected as the population because they are in close contact with potential and actual tourists and are regarded as knowledgeable on tourists' sentiments about a single visa for the SADC region, and also because they would be directly affected by the introduction of the Univisa. Hughes and Allen (2009) studied the impact of the EU accession of 2004 on the tourism industry of Central and Eastern Europe, using a sample of tourist board managers. They observe that an alternative approach would have been to obtain tourists' views, but they note that these views would have been more micro and individualistic and less well informed. This would also have been the case for our research study. Hughes and Allen (2009) also note that the views of other key stakeholders in the tourism industry, such as tour operators, could offer another perspective, and our target population of tour operators was established on the basis of this suggestion. They further suggest that a study of the actual behaviour and reactions (as opposed the views) of UK tourists after the 2004 accession could provide some insight into whether or not, from a consumer viewpoint, the accession did influence travel (at least for this market), and this could possibly be a future research direction for our study.

The two samples used in this study consisted of inbound tour operators operating in the 14 countries of the SADC region and receiving tourists from outside the region and outbound tour operators based in either Europe or America and packaging tours to the SADC region. Non-probability convenience sampling was used since no single database exists of all the tour operators sending tourists to the SADC region and receiving them. The population of inbound and outbound tour operators was selected by using first paper based tourism directories and second an internet search. The internet search was continued until saturation point was reached; in other words, where no new additional tour operators were being identified. These searches delivered 500 inbound tour operators and 160 outbound. Two online quantitative surveys were developed, both containing questions about the tour packages that the respective tour operators were currently offering to potential clients, their perceptions regarding the existing visa requirements for the SADC region, and how they thought the 
possible implementation of the Univisa would influence the number of tourist arrivals to the region. An email containing a link to the survey was sent to both types of tour operator, followed by two reminder emails. The target was to receive as many responses as possible, but with a lower limit of no fewer than six responses per country for the SADC region (inbound operators) and 20 in total from the outbound operators. We received 71 completed questionnaires from the former and 21 from the latter. Table 2 shows a breakdown of the responses.

Table 2: Breakdown of responses

\begin{tabular}{lc}
\hline Country & Response count \\
\hline Inbound operators & 1 \\
Angola & 7 \\
Botswana & 2 \\
DRC & 0 \\
Lesotho & 3 \\
Madagascar & 4 \\
Malawi & 2 \\
Mauritius & 5 \\
Mozambique & 9 \\
Namibia & 17 \\
South Africa & 0 \\
Swaziland & 5 \\
Tanzania & 5 \\
Zambia & 11 \\
Zimbabwe & $\mathbf{7 1}$ \\
Total & \\
Outbound operators & 2 \\
USA & 19 \\
Europe & $\mathbf{2 1}$ \\
Total & \\
\hline
\end{tabular}

The relatively low number of responses was not surprising, since response rates to surveys have declined dramatically (Sax et al., 2003:423). Reasons proposed for declining response rates vary from the increase in 'junk mail' to the proliferation of web-based questionnaires. Respondents feel increasingly bombarded with questionnaires, whether paper or internet based, and given today's increasingly fast-paced culture and the increasing demands on their time may be less prepared to commit themselves to a voluntary activity like completing a survey (Sax et al., 2003:423).

A further reason for the low number of responses was the time frame of the project, which did not allow for collecting further responses. Besides the low response rate, other limitations of the study were the language barrier (some of the responses indicated that respondents did not understand English very well), the bandwidth in some African countries (it took some respondents up to 40 minutes to download the questionnaire), and some respondents' limited knowledge and understanding of the Univisa. These three factors could also explain the low response rate. It should be noted that some of the questionnaires were not fully completed. We did not want to force respondents to answer all the questions, so not all questions were answered by all 71 inbound and 21 outbound operators. 


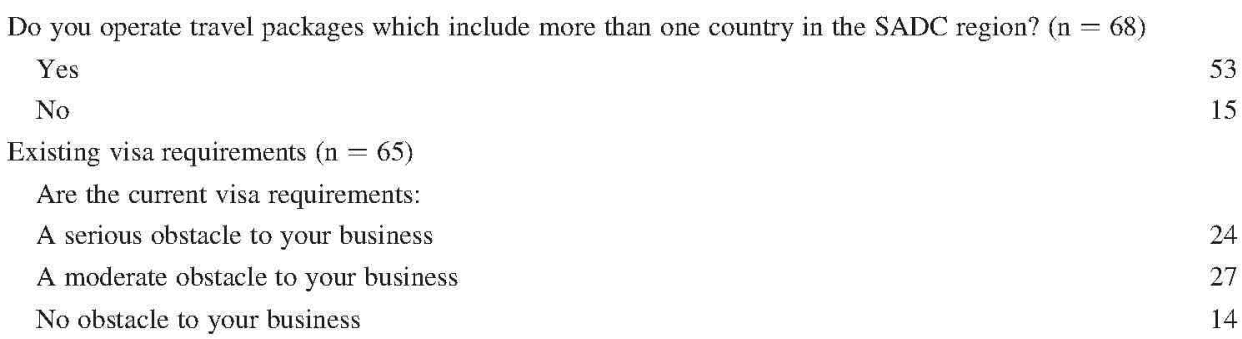

Potential effect of the Univisa on tour operators' businesses

What would the effect of the Univisa be on your business? $(n=65)$

Positive

Negative

No effect

I am not sure

With the Univisa in place, would your company expect an increase in its number of clients? $(\mathrm{n}=63$ )

Yes

No

I am not sure

With the Univisa in place, would you consider operating new multi-country packages? $(n=63)$

Yes

No

I am not sure

If yes, to which of the following countries? $(n=52)$

Angola

Botswana

DRC

Lesotho

Madagascar

Malawi

Mauritius

Mozambique

Namibia

South Africa

Swaziland

Tanzania

Zambia

Zimbabwe

With a Univisa in place, do you think your company would save costs? ( $\mathrm{n}=64)$

Yes

With a Univisa in place, do you think your company would save administrative hassle? $(\mathrm{n}=63$ )

Yes

No

Should the Univisa be introduced, do you expect your clients' length of stay to increase per trip? $(\mathrm{n}=61)$ Yes

\section{Results}

Due to the low response rate, analysis of the quantitative data consisted of descriptive statistics, and more specifically frequency counts. Although frequency counts do not provide statistically significant results, they nevertheless give some indication of market trends. 


\subsection{Inbound tour operators}

\subsubsection{Current tour packages}

Table 3 shows the travel packages that inbound tour operators were offering at the time of the study. Most were offering trips to more than one country in the SADC region, the most frequently mentioned being Zambia, Zimbabwe, South Africa and Botswana. According to these tour operators' responses, $47 \%$ (on average) of their inbound clients visited more than one country in the region, and they estimated that $48 \%$ (on average) of all holiday tourists did this.

\subsubsection{Existing visa requirements}

Table 3 also indicates the inbound operators' opinions of the current SADC visa requirements. The majority (51 out of 65) of respondents said that the they were an obstacle to their businesses. Of the 51, 27 regarded the requirements as a moderate obstacle, while 24 saw them as a serious obstacle. Respondents were also asked to indicate the factors which they consider to be bigger obstacles to the development of the tourism industry in their respective countries than the current visa requirements. The results are shown in Table 4.

Table 4: Obstacles to tourism development (inbound tour operators, $n=65$ )

\begin{tabular}{lc}
\hline & Number of \\
Problem & responses \\
\hline National tourism marketing & 18 \\
The government does not give priority to tourism development & 23 \\
Transport & 19 \\
General infrastructure (e.g. water, electricity, communication networks, medical & 21 \\
services) & 20 \\
The political situation in the country & 22 \\
Price & 18 \\
Security & 12 \\
The current visa requirement is the greatest obstacle to the development of tourism in & \\
the country & 5 \\
There are no obstacles to the development of tourism in the country & 15 \\
Other (please specify) &
\end{tabular}

Table 4 shows that the inbound operators considered the current visa requirements the least serious obstacle to the development of the tourism industry in the respective countries. They picked the fact that tourism development was not given government priority as the most serious obstacle, followed closely by high pricing within the destination, and the lack of suitable infrastructure. Among other factors they mentioned as obstacles were political instability (as in Zimbabwe, for example), immigration, ${ }^{3}$ police harassment of drivers with

\footnotetext{
${ }^{3}$ We were unfortunately unable to ask this respondent what he meant by 'immigration'. We assume he might have meant that foreigners were taking jobs in the tourism industry and thus hampering efforts by locals, or he might have been referring to illegal immigrants, often perceived to be involved in crime and thus as an obstacle to tourism development, or his response might be linked to xenophobia, which inhibits tourism development.
} 
foreign registered vehicles, economic factors such as unfavourable exchange rates and increases in park fees, and general tourism industry problems such as the 'closed skies' policy in South Africa that results in high air fares for international visitors, the limited flights available into the region, the red tape and high costs that tour operators have to bear for registration and licensing, a lack of cohesive forward planning, and the fact that tour guides are not allowed to work in all the countries in the region. A statement from one a respondents based in Victoria Falls was of particular relevance to this study:

All our clients wish to see the Victoria Falls from both sides, so a visa is needed for both Zambia and Zimbabwe. Whichever country they are staying in, they need a double entry visa to get back into that country. Also, clients wish to visit Chobe in Botswana, so that means a multiple entry visa is required, which cannot be bought at the border. It is a very serious situation which needs to be addressed immediately.

\subsubsection{Potential effect of the Univisa on tourist arrivals}

Table 3 also indicates the possible effect that the inbound operators thought the Univisa would have on tourist arrivals to the SADC region and ultimately on their businesses. Most were optimistic about such a development, particularly in terms of tourism growth, though some were not sure what the effect of the Univisa would be on their businesses. Most expected an increase in their client numbers as a result of the Univisa implementation, estimating, on average, a 35\% increase. Only nine respondents did not foresee any increase in clients as a result of the Univisa. The number of respondents expecting an increase in clients is relatively low compared to the number expressing optimism about the possible effects that the Univisa would have on their businesses. This discrepancy could indicate that their support of the Univisa could pertain to more than merely the possibility of increased revenue and might include other aspects as well. When asked if they would consider operating new multicountry packages should the Univisa be introduced, most responded positively. The country that inbound tour operators were most likely to include if they were to introduce new multicountry packages (other than the countries they already included) was Botswana, followed by Zambia, Zimbabwe and Namibia. When indicating the area in which the Univisa would bring greatest benefit to the company in terms of savings, more respondents expected a reduction in administrative problems than a reduction in costs. For these operators, the average length of stay per trip was 9.5 days, with 20 days being the longest and two days the shortest. Most said they expected an increase in the length of stay as a result of the Univisa.

\subsection{Outbound tour operators}

\subsubsection{Current tour packages}

Table 5 shows that 18 of the 21 outbound tour operators confirmed that they offered single country tours to the SADC region, with the most popular being Namibia and South Africa, followed by Botswana and Tanzania. Almost all outbound tour operators offered multiple country tours to the SADC region, with the most being South Africa, Zambia, Namibia and Botswana. These tour operators were requested to estimate the percentage of their customers that booked multiple country tours to Southern Africa. The average was calculated to be $58 \%$. 
Table 5: Responses from outbound operators

Current tour packages

Do you offer single country tours? $(n=21)$

Yes

No

If yes, to which countries? $(\mathrm{n}=18)$

Angola

Botswana

2

DRC

Lesotho

Madagascar

Malawi

Mauritius

8

Mozambique

10

Namibia

7

South Africa

16

Swaziland

Tanzania

12

Zambia

Zimbabwe

Do you offer multiple country tours? $(\mathrm{n}=21)$

Yes

No

If yes, to which countries? $(\mathrm{n}=20)$

Angola

Botswana

DRC

Lesotho

Madagascar

Malawi

Mauritius

Mozambique

Namibia

South Africa

Swaziland

Tanzania

Zambia

Zimbabwe

Existing visa requirements

For their trip to southern Africa, what percentage of your customers require: $(\mathrm{n}=20)$

No visa

One visa

Two or more visas

Potential effect of the Univisa on tour operators' businesses

What would the effect of the Univisa be on your business? $(n=20)$

Positive 


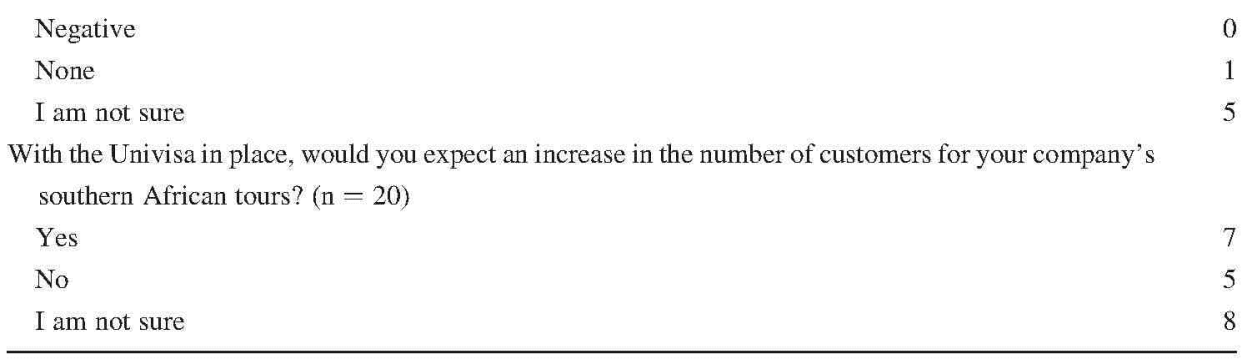

\subsubsection{Existing visa requirements}

Table 5 shows that outbound tour operators said that $50 \%$ (on average) of their customers required no visa, $36 \%$ (on average) required one visa and $18 \%$ (on average) needed two or more visas for their trip to southern Africa. In response to the question whether the current visa requirements of southern African countries were an obstacle when selling their tour packages to these countries, six outbound tour operators said they were no obstacle and 13 that they were a moderate obstacle. Only one felt that these requirements were a big obstacle.

\subsubsection{Potential effect of the Univisa on tourist arrivals}

In response to the question about the expected overall effect of the Univisa on their businesses, 14 respondents thought it would be positive, while five were not sure what the effect would be. None of the respondents thought that the Univisa would have a negative effect on their businesses. The operators' responses to more specific questions about the Univisa's effect were less positive, with only seven (out of 20) expecting an increase in their number of customers. Eight respondents (out of 20) were not sure whether to expect an increase or not. Most said they would consider operating new multiple country tours with the Univisa in place, and all of them were interested in operating new packages to Zambia, while 16 were interested in operating new packages to Zimbabwe and 12 to Tanzania. In response to the question whether they would save on costs and administrative problems, should the Univisa be introduced, these operators were more positive about the latter than the former.

Table 6 shows the factors that outbound operators considered to have a more negative effect on the selling of southern African destinations than the current visa requirements. These were (in order of importance) political instability, high prices and inadequate security.

Table 6: Factors considered to have a more negative effect on the selling of the destination than the current visa requirements (outbound tour operators, $n=18$ )

\begin{tabular}{lc}
\hline Factors & Number of responses \\
\hline Government policy & 8 \\
Security & 13 \\
Political situation & 15 \\
National tourism marketing & 2 \\
Price & 16 \\
Tourism infrastructure & 7 \\
\hline
\end{tabular}




\section{Discussion and conclusion}

This study investigated the perceptions of tour operators in the SADC region and in America and Europe to discover whether they considered the proposed Univisa would improve the accessibility of the SADC region, increase visitor numbers and ultimately encourage tourism development in the region. To our knowledge this is the first study to examine perceptions of the potential impact of a regional visa, and indeed also the first study to determine the potential impact of the proposed Univisa on the accessibility of a tourism destination. This research study could be useful for planners considering the establishment of transfrontier conservation areas (TFCA). These are areas that aim to encourage the freer movement of animals without artificial human boundaries. The introduction of the Univisa would also encourage the freer movement of tourists in these areas. This is a possible effect of the Univisa on TFCAs could be taken up in future research. ${ }^{4}$

Both inbound and outbound tour operators in the study sample were generally positive about the proposed Univisa, since many of them felt that the current visa requirements were an obstacle to their businesses, though not the worst obstacle they faced. Although operators were generally excited about the prospect of the increased visitor numbers that the Univisa could bring, the outbound operators were more cautious and unsure about the extent to which the Univisa would happen. Both inbound and outbound operators said they would consider operating new multi-country packages, should the Univisa be introduced. Both types of operator were more positive about the Univisa saving them administrative difficulties than saving them costs, and the outbound operators in particular were not convinced that the Univisa would save them costs.

From the responses it was evident that inbound tour operators felt quite positive about tourism development in their countries, with only just over a third complaining about the prices in the SADC region and the fact that their governments did not give priority to tourism development. However, inbound operators also felt that the political situation in their countries, and the state of the infrastructure, were obstacles to tourism development in the SADC region. What is more, inbound operators indicated that all the factors listed in the questionnaire as obstacles to tourism development were more serious than the current visa requirements of the region. Outbound tour operators were less positive about the SADC region and said that security, the political situation in some countries in the region and the region's prices all had a major effect on the selling of packages to the region. The responses certainly suggested that there are more serious problems for the development of the SADC region as a tourism destination than the current visa requirements. The implication for SADC is that before they spend money and time on developing and implementing the Univisa they need to deal with the many serious problems that are hindering the region's development as a tourism destination of choice: political and security problems, unhelpful government policy on tourism in the region, and inadequate infrastructure.

The limitations of this study have been mentioned above. Future research could expand on this study's findings by using tourists rather than operators as respondents. This could perhaps provide a clearer understanding of whether the Univisa would indeed result in increased visitor numbers and visitor spending. Future research related to the Univisa could also explore the topic of regional cooperation in Africa, in particular the possibility of a single accreditation scheme for tourist accommodation in southern Africa. ${ }^{5}$

\footnotetext{
${ }^{4}$ The authors are indebted to an anonymous reviewer for this interesting suggestion.

${ }^{5} \mathrm{We}$ are also indebted to the anonymous reviewer for this suggestion.
} 
It is hoped that this study has provided some insight into the complexities of a regional visa and incidentally highlighted the urgency of addressing specific barriers to tourism development in a region which is rich in natural and cultural attractions. While a regional visa would alleviate some problems, mostly of an administrative nature, it cannot be seen as an answer to the slow development of tourism in this region.

\section{References}

Boratyński, J \& Szymborska, A, 2006. Neighbours and visas: Recommendations for a friendly European Union visa policy. http://pdc.ceu.hu/archive/00003173/01/neighbours-and-visas.pdf Accessed 25 March 2010.

Brown, DO, 2000. Political risk and other barriers to tourism promotion in Africa: Perceptions of US-based travel intermediaries. Journal of Vacation Marketing 6(3), 197-210.

Cleverdon, RG, 2002. Tourism development in the SADC region: The opportunities and challenges. Development Southern Africa 19(1), 7-28.

Coles, T \& Hall, D, 2005. Tourism and European Union enlargement. Plus ça change? International Journal of Tourism Research 7(2), 51-61.

Dabour, NM, 2001. Tourism development in the OIC countries: Further steps towards promotion of cooperation. Journal of Economic Cooperation 22(4), 51-84.

EIF (Enhanced Integrated Framework), 2003. Integration into the World Trading Environment Lesotho.

www.enhancedif.org/documents/DTIS\%20english\%20documents/english/Lesotho_DTIS \%20Vol.1.pdf Accessed 25 March 2010.

Enright, MJ \& Newton, J, 2005. Determinants of tourism destination competitiveness in Asia Pacific: Comprehensiveness and universality. Journal of Travel Research 43(5), 339-50.

European Commission, n.d. Travelling in Europe: Schengen. http://ec.europa.eu/youreurope/nav/en/citizens/travelling/schengen-area/index.html Accessed 15 March 2010.

Ferreira, S, 2004. Problems associated with tourism development in southern Africa: The case of transfrontier conservation areas. GeoJournal 60, 301-10.

Gauci, A, Gerosa, V \& Mwalwanda, C, 2002. Tourism in Africa and the Multilateral Trading System: Challenges and opportunities. Background paper, Economic Commission for Africa.

http://citeseerx.ist.psu.edu/viewdoc/download?doi=10.1.1.116.8620\&rep=rep1\&type=pdf Accessed 1 April 2010.

Heath, E, 2002. Towards a model to enhance Africa's sustainable tourism competitiveness. Journal of Public Administration 37(3.1), 327-53.

Hughes, HL \& Allen, D, 2009. Central and Eastern Europe and EU accession 2004: Views of the impact on tourism. Tourism and Hospitality Research 9: 185-98.

Konečnik, M, 2002. A review of air transport and tourism in Europe: The past, present and future. Proceedings of the 52nd International Association of Scientific Experts in Tourism (AIEST) Congress, Salvador da Baía, Brazil, 18-23 August, pp. 273-97.

Laitinen, K, 2004. The perceptions of tour guides of Finland as a travel destination for Chinese tourists. MA thesis, European Tourism Management, Bournemouth University. http://du.se/PageFiles/5051/Laitinen,\%20Kirsti\%20thesis.pdf Accessed 27 April 2010.

Naude, WA \& Saayman, A, 2005. Determinants of tourist arrivals in Africa: A panel data regression analysis. Tourism Economics 11(3), 365-91.

Page, S, 1999. Tourism and development: The evidence from Mauritius, South Africa and Zimbabwe. www.odi.org.uk/resources/download/2932.pdf Accessed 19 February 2010. 
Puczko, L \& Ratz, T, 2006. Product development and diversification in Hungary. In Hall, D, Smith, M \& Marciszweska, B (Eds), Tourism in the New Europe: The Challenges and Opportunities of EU Enlargement. CABI, Wallingford, UK, pp. 116-26.

Rannditsheni, R, 2008. Southern African Development Community (SADC) closer to establishing One Visa (Univisa) for tourists. www.info.gov.za/speeches/2008/08032611451001.htm Accessed 18 March 2010.

Reinstein, D, 2011. Will SADC univisa become a reality? www.tourismupdate.co.za/NewsDetails.aspx?newsId=58545 Accessed 13 May 2011.

RETOSA (Regional Tourism Organisation of Southern Africa), n.d. The Tourist Visa (Univisa). www.retosa.co.za/regional-initiatives/tourist-visa Accessed 23 March 2010.

RETOSA (Regional Tourism Organisation of Southern Africa), 2009. The Tourist Visa (UNIVISA). -RETOSA. www.retosa.co.za/regional-initiatives/tourist-visa Accessed 23 May 2012.

RETOSA (Regional Tourism Organisation of Southern Africa), 2010. Univisa passport marketing tool forerunner to the real deal. www.retosa.co.za/news/2010_02 Accessed 18 March 2010.

Rogerson, CM \& Visser, G, 2004. Researching the South African tourism and development nexus. Geojournal 60, 201-15.

Rogerson, CM \& Visser, G, 2006. International tourist flows and urban tourism in South Africa. Urban Forum 17(2), 199-213.

SADC (Southern African Development Community), 2009. SADC profile, vision and objectives. www.sadc.int/index/browse/page/52 Accessed 19 May 2012.

Sax, L, Gilmartin, S \& Bryant, A, 2003. Assessing response rates and non-response bias in web and paper surveys. Research in Higher Education 44(4): 409-32.

Smeral, E, 2009. Impacts of the world recession and economic crisis on tourism: Forecasts and potential risks. Journal of Travel Research 49(1), 31-8.

Tchorbadjiska, A, 2007. Bulgarian experiences with visa policy in the accession process: A story of visa lists, citizenship and limitations on citizens' rights. Regio - Minorities, Politics, Society (English Edition) 1, 88-105.

Tosun, C, Timothy, DJ, Parpairis, A \& Macdonald, D, 2005. Cross-border cooperation in tourism marketing growth strategies. Journal of Travel \& Tourism Marketing 18(1), 5-23.

Tretheway, M \& Mak, D, 2006. Emerging tourism markets: Ageing and developing economies. Journal of Air Transport Management 12, 21-7.

WEF, WB \& ADB (World Economic Forum, World Bank \& African Development Bank),2011. The Africa Competitiveness Report 2011.

http://allafrica.com/download/resource/main/main/idatcs/00020871:8271c57549b50d7ac3 a26afcb10b2bc7.pdf\#page=106 Accessed 12 May 2011.

Whyte, RB, 2009. Visa-free travel: An Indicator of global integration. Eurasion Development Bank (EDB) Eurasian Integration Yearbook 2009. http://212.108.98.114/media/img/eng/research-andpublications/IntegrationYearbook/2009/a_n2_2009_22.pdf Accessed 20 May 2012.

Zambian Economist, 2008. A SADC Schengen? Zambian Economist 13 March 2008. www.zambian-economist.com/2008/03/sadc-shengen.html Accessed 18 March 2010. 